\title{
DO HEMORHEOLOGICAL LABORATORY ASSAYS HAVE ANY CLINICAL RELEVANCE?
}

\section{(Contribution to the Round Table Discussion at the 9th European Conference on Clinical Hemorheology, Siena June 29-July 1, 1995)}

Sandro Forconi, Maurizio Guerrini.

Institute of Internal Medicine and Geriatrics, School of Medicine

University of Siena 53100 - Siena, Italy

The concept of blood fluidity, known from the time of Pouiselle, entered the clinical world when it became possible to measure in some way blood viscosity and when clinicians could understand that the non-Newtonian properties of blood depend on the different blood components (Fig. 1)

Everybody can easily see that a simple increase of one of the components (number of cells, amount of fibrinogen or of proteins) can cause an increase in blood viscosity. Therefore, the simple evaluation of the components can give us information about the behavior of blood viscosity (Table I)

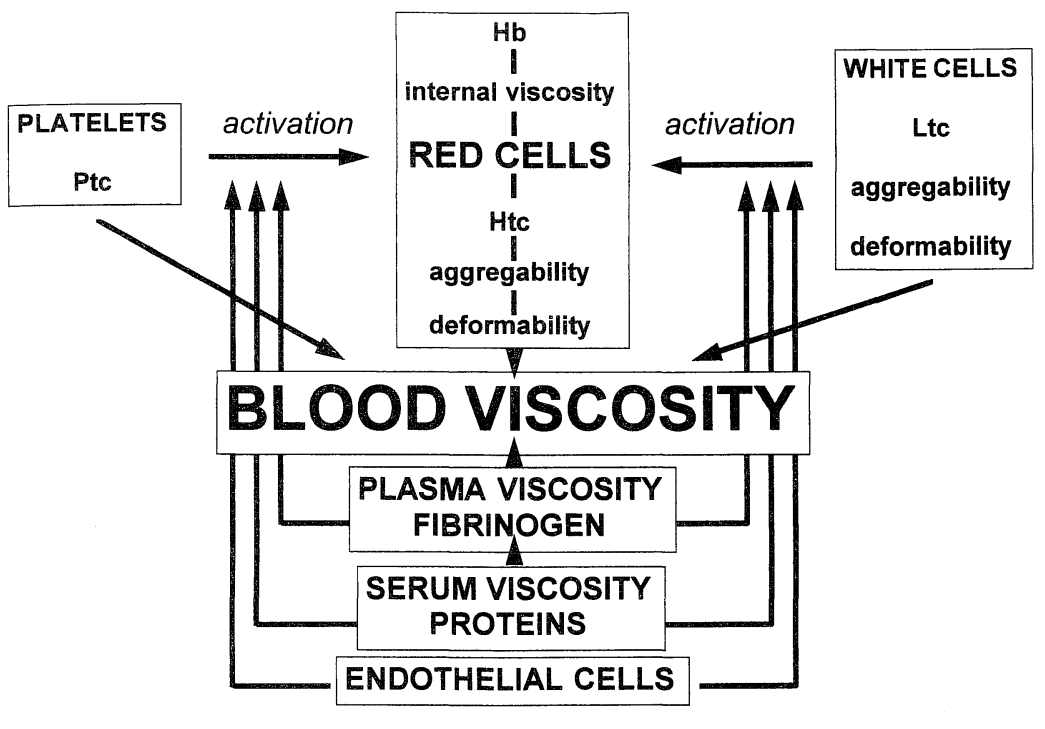

FIG. 1

Different components affecting rheological properties of blood 
TABLE I

Hematological Parameters From Which It Is Possible To Gain Information About Blood Rheology

\section{Hemochrome: \\ Hematocrit \\ Red cell count \\ Platelets \\ Fibrinogen \\ Plasma proteins \\ Immunoglobulins \\ Lipids}

White cell count

Mean Corpuscular Volume (MCV)

Erythrosedimentation Rate

TABLE ॥

List Of Instruments

\section{VISCOMETERS}

Rotational viscometers

Cone-plate:

Wells-Brookfield

Carri-Med

Coaxial-cylinders:

Haake Rotovisco

Contraves

Capillary viscometers

\section{FILTROMETERS}

- Hemorheometer (Hanss)

- Reid and Dormandy (Nucleopore membrane)

- whole blood

- cells suspended in plasma

- cells suspended in buffer

- Forconi $\left(37^{\circ} \mathrm{C}\right)$

- St. George Filtrometer

EKTACYTOMETERS - SILLECTOMETERS

- Technicon

- Myrenne

- Laser-Assisted Optical Rotational Cell Analyser (L.O.R.C.A.)

\section{OTHERS}

- Rheoscope

- Single erythrocyte rigidometer

- MF4 (Teitel)

- Micropipette 
However, everybody can see that viscosity is the result also of the interaction of the plasma components with the circulating cells, which release substances that can come also from endothelium, and contribute to the "in vivo" flow properties of blood. Thus, while a term like "Viscosity" can easily be understood, and measured, because it is a precise physical entity, other terms like "Aggregability" or "Deformability" are more difficult both to understand and to measure. Hence, clinicians have used proper instruments called "Viscometers" and "Aggregometers", and have tried to evaluate "Deformability" with "Filtrometers" (it was often hard to convince people that filtrability and deformability are not the same thing). Table II is a list of instruments that have been used till now.

Have these instruments been useful for the progress of clinical hemorheological knowledge? Is the study of blood fluidity important? In 1981, during the Meeting of the Group for the Study of Red Cell Deformability and Filterability, which was the group that founded Clinical Hemorheology, John Dormandy (1) posed the same questions:

1) Is increased blood viscosity a risk factor for diseases?

2) Does it participate in the pathogenesis of disease?

$3)$ Is it related to the severity of diseases?

4) Is it related to the prognosis?

5) Does hemorheological treatment improve the course of disease?

We can easily say "Yes" to all these questions. We know diseases like the Blood Hyperviscosity Syndromes (2-4) (Fig. 2). And we can give this answer because measurements made with viscometers and filtrometers strongly contributed to the studies of circulatory pathophysiology.

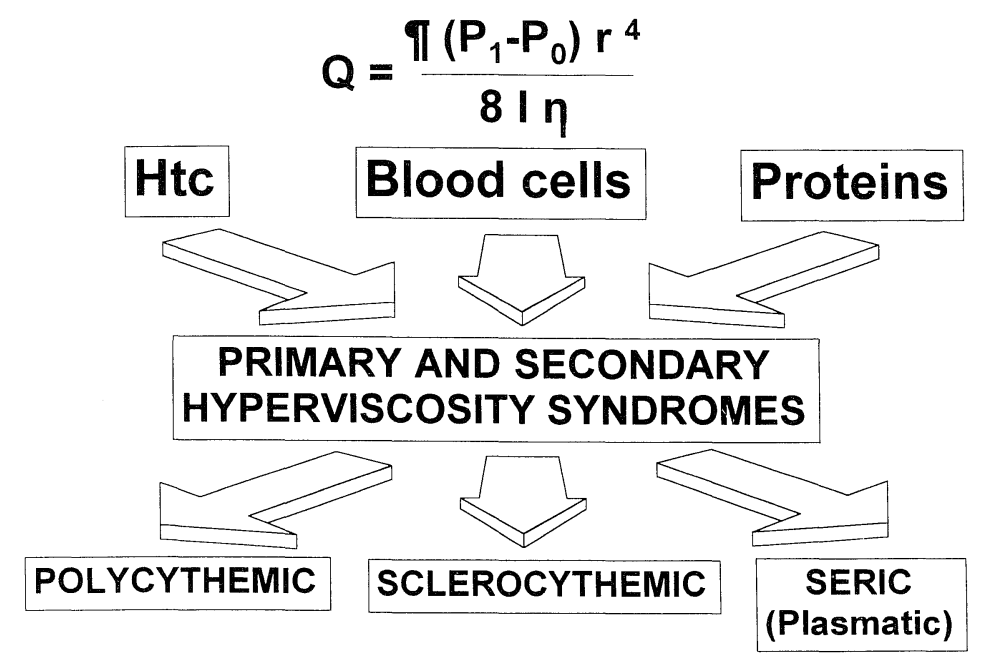

FIG. 2

Role of blood components in the determination of hyperviscosity syndromes 
However some important facts must be accepted. We said that viscosity is a physical entity, but it is not completely possible to measure in a really exact way a non-Newtonian fluid like blood. In other words, it is not the same thing to measure glycemia for the follow-up of diabetic patients and blood viscosity for patients with Hyperviscosity Syndromes. This difficulty is due to the fact that we measure hemorheological parameters not "in vivo" but "ex vivo". We draw a blood sample from the vein and we place the measurement "in vitro": but the behavior of blood "in vitro" is different from that "in vivo". The viscometers at our disposal have been planned for industrial use and for the measure of fluids that are very different from blood. Calibration of the instruments is made with Newtonian fluids, also when we measure blood! The "gold standard" for viscosity could be different according to the different manufacturers. Scholars can use similar instruments, but the measurements are generally made at different shear rates and there is not the same standardization in the different laboratories. We measured the same blood with two different instruments (same blood, measurements made in triplicate without storage with a Carri-Med and with a Haake Rotovisco viscometer at two different shear rates. The correlation is shown in Figs. 3 and 4. It is clear that when viscosity is high (or low) with one instrument, is high (or low) also with the other instrument, but the correlation is poor.

\section{VISCOMETERS COMPARISON shear rate $10 \mathrm{~s}^{-1}$}

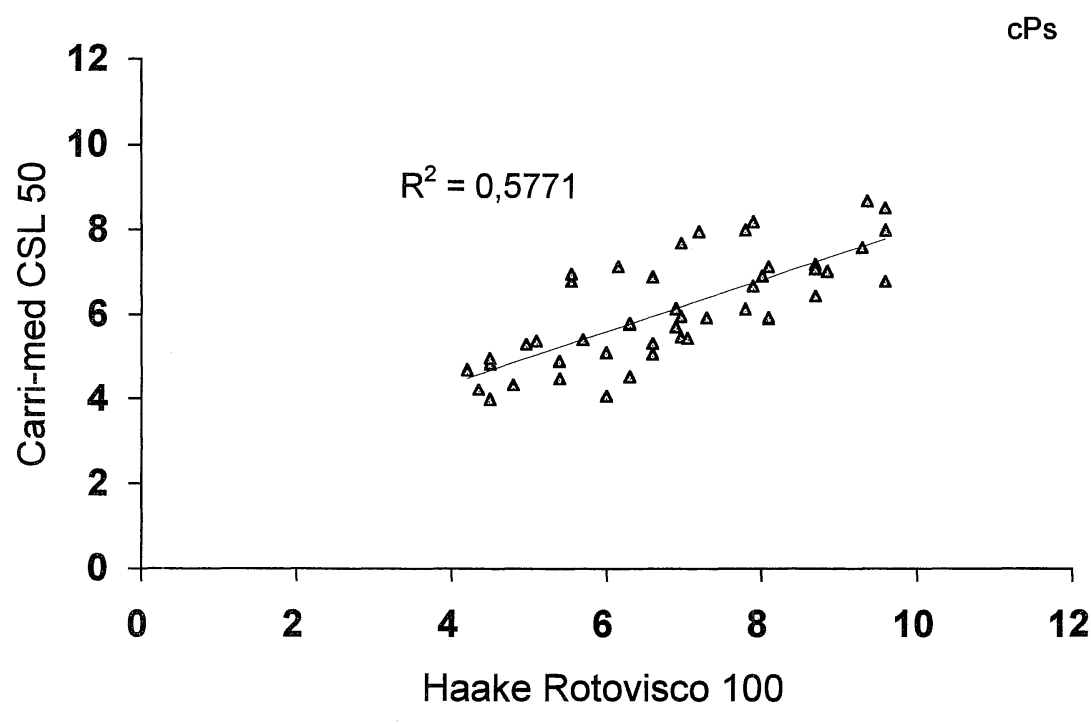

FIG. 3

Comparison between blood viscosity values measured by two different viscometers at $10 \mathrm{~s}^{-1}$ shear rate. Statistical analysis performed through linear regression 


\section{VISCOMETERS COMPARISON shear rate $40 \mathrm{~s}^{-1}$}

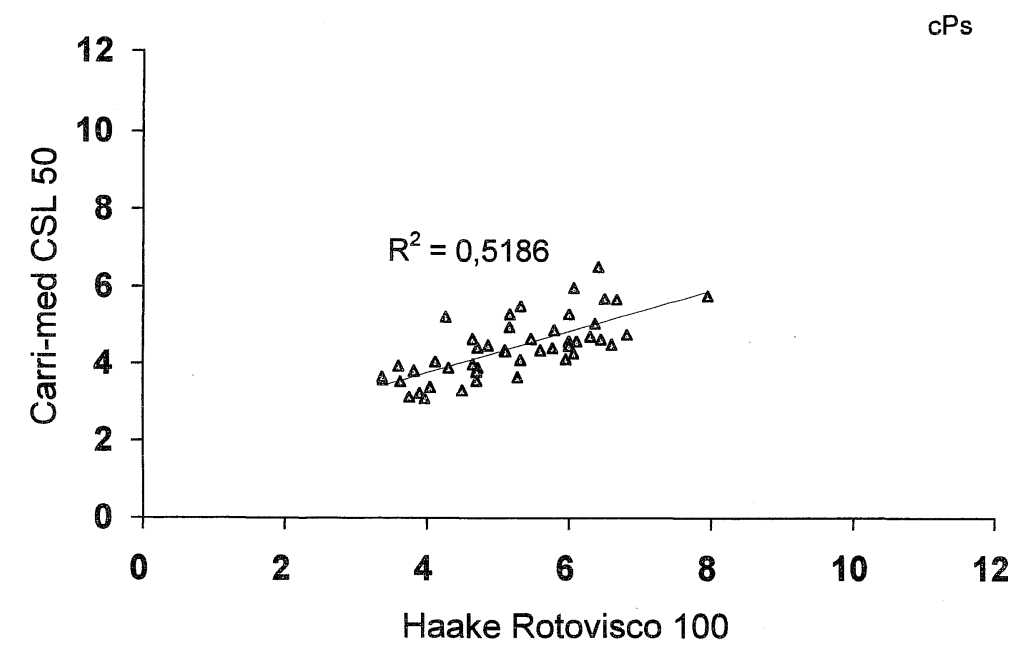

FIG. 4

Comparison between blood viscosity values measured by two different viscometers at $40 \mathrm{~s}^{-1}$ shear rate. Statistical analysis performed through linear regression

There is no time to mention all the controversies about Blood Filterability. Reid and Dormandy's (5) method was important because it was simple and inexpensive. With our modification we have obtained very interesting results (6-10). However it must be clear: that filterability is not deformability; that filtering whole blood is different from filtering washed red cells; that we have to consider white cells, etc. etc.

In conclusions, blood tests do have clinical relevance, but in the hands of expert clinicians who know their limits. They have contributed to the progress of the science, but now that we have much more information about rheological pathophysiology, also simple tests like HTC or ESR can be sufficient for normal clinical use.

We also must not forget the information that can be obtained from very simple and inexpensive methods. Among these, we cite a simple technique based on the observation, with an optical microscope, of the red cell in a three-dimensional way (Zipursky). Because of its simplicity, it can be adopted in every laboratory and can provide the possibility of dicovering the presence of red cells with normal (bowls, discocytes) and pathological shape (echinocytes, knizocytes, etc.) and their different percentages in various diseases (11-14).

\section{REFERENCES}

1. DORMANDY, J. Red Cell Deformability and Filterability. Martinus. Nijhoff Publs. Boston 1983, p. 176.

2. DI PERRI, T., FORCONI, S., DI LOLLO, F., POZZA, G. Le sindromi da iperviscosità ematica. Fisiologia, patologia e clinica. L. Pozzi (Ed.), Roma 1983, pp.1-122. 
3. WELLS, R. Syndromes of hyperviscosity. New Engl. J. Med. 283, 183, 1970.

4. FORCONI, S., PIERAGAlli, D., GUERRINI, M., DI PERRI, T. Hemorheology and peripheral arterial diseases. Clinical Hemorheology 7, 145-158, 1987.

5. REID, H.L., BARNES, A.J., LOCK, P.J., DORMANDY, J.A., DORMANDY, T.L. A simple method for measuring erythrocyte deformability. J. Clin. Path. 29, 855, 1976.

6. FORCONI, S. Can red cell deformability be measured in clinical medicine? Clinical Hemorheology 9, 27, 1989.

7. FORCONI, S. Clinical significance of filtration tests in peripheral and myocardial ischaemia. In: Red Cell Deformability and Filterability. J. Dormandy (Ed.) Martinus Nijhoff Publs. Boston 1983, p.198.

8. FORCONI, S., GUERRINI, M., PIERAGALli, D., ACCIAVATTI, A., DEL BIGO, C., GALIGANI, C., DI PERRI, T. Rilievi metodologici sulla filtrazione del sangue intero nella valutazione della deformabilità eritrocitaria. Nota I: effetto della temperatura. $L a$ Ricerca ('lin. Lab. 13 (suppl.3), 271-276, 1983.

9 FORCONI, S., GUERrini, M., ACCIAVATti, A., PIERAGAlli, D., DEL BIGO, C., GALIGANI, C., RALLI, L., DI PERRI, T. Rilievi metodologici sulla filtrazione del sangue intero nella valutazione della deformabilità eritrocitaria. Nota II: effetto del tempo di conservazione a varie temperature. La Ricerca Clin. Lab. 13 (suppl.3), 277-282, 1983.

10. Forconi, S., GUERrini, M., Pieragalli, D., DEl BIGO, C., GAligANi, C., ACCIAVATTI, A., DI PERRI, T. Rilievi metodologici sulla filtrazione del sangue intero nella valutazione della deformabilità eritrocitaria. Nota III: influenza relativa delle diverse componenti cellulari. La Ricerca Clin. Lab. 13 (suppl.3), 283-288, 1983.

11. ZIPURSKY, A., BROWN, E., PALKO, J., BROWN, E.J. The erythrocyte differential count in newborn infants. The American Journal of Pediatric Hematology/Oncology, 5, $45-51,1983$

12. DE MATTEIS, C., GUERRINI, M., FORCONI, S. Presentazione di una metodica per lo studio con microscopio ottico della morfologia eritrocitaria. Atti del $V$ Congresso Nazionale della Società Italiana di Emoreologia Clinica. McGraw-Hill, 297-300, 1992.

13. DE MATTEIS, C., TURCHETTI, V., GUERRINI, M., ZIPURSKY, A., FORCONI, S. Behaviour of erythrocytic morphology in several pathologies. Clinical Hemorheology, 15 (3), 444, 1995.

14. TURCHETTI, V., DE MATTEIS, C., LEONCINI, F., PICCIOLINI, F., GUERRINI, M., ZIPURSKY, A., FORCONI, S. Evaluation of erythrocytic morphology in vasculopatic subjects with and without diabetes: comparison with blood viscosity and intraerithrocytic calcium. (linical Hemorheology, 15 (3), 519, 1995. 